Uniwersytet PrzyrodniczoHumanistyczny w Siedlcach

Siedlce University of Natural Sciences and Humanities

https://bazawiedzy.uph.edu.pl

\begin{tabular}{|l|l|}
\hline Publikacja / Publication & $\begin{array}{l}\text { Historyczne spojrzenie Komeńskiego na dziejowe losy Czech i jego kościoła } \\
\text { (zwłaszcza Jednoty Braci Czeskich - Unitas Fratrum), } \\
\text { Hampl Lubomir }\end{array}$ \\
\hline $\begin{array}{l}\text { Adres publikacji w Repozytorium } \\
\text { URL / Publication address in } \\
\text { Repository }\end{array}$ & https://bazawiedzy.uph.edu.pl/info/article/UPH2dfc32369b4e4730ad3e997ef86f9410/ \\
\hline $\begin{array}{l}\text { Data opublikowania w Repozytorium / } \\
\text { Deposited in Repository on }\end{array}$ & 22 paź 2021 \\
\hline Rodzaj licencji / Type of licence & Attribution-NoDerivs (CC BY-ND 3.0) \\
\hline Cytuj tę wersję / Cite this version & $\begin{array}{l}\text { Hampl Lubomir: Historyczne spojrzenie Komeńskiego na dziejowe losy Czech i } \\
\text { jego kościoła (zwłaszcza Jednoty Braci Czeskich - Unitas Fratrum), Siedleckie } \\
\text { Zeszyty Komeniologiczne seria PEDAGOGIKA, no. 6, 2019, pp. 365-383 }\end{array}$ \\
\hline
\end{tabular}




\title{
HISTORYCZNE SPOJRZENIE KOMEŃSKIEGO NA DZIEJOWE LOSY CZECH I JEGO KOŚCIOŁA (ZWŁASZCZA JEDNOTY BRACI CZESKICH - UNITAS FRATRUM)
}

\author{
COMENIUS' HISTORICAL VIEW OF THE HISTORICAL FATE \\ OF THE CZECH AND THEIR CHURCH (ESPECIALLY THE UNITY \\ OF THE CZECH BRETHREN - UNITAS FRATRUM)
}

DOI: $10.5604 / 01.3001 .0013 .6263$

\begin{abstract}
Streszczenie: Niniejszy artykuł koncentruje się na książce Jana Amosa Komeńskiego pt. Historie o těžkých protivenstvích církve české - vjazyce 21. století. Oryginalny, siedemnastowieczny tekst zostal uwspółcześniony, napisany językiem 21 wieku (zdecydowanie ułatwia to odbiór i lepsze zrozumienie staroczeskich tekstów literackich). Żeby lepiej poznać twórczość „nauczyciela narodów", zdecydowałem się dla polskojęzycznego czytelnika przetłumaczyć wybiórczo dwa rozdziały. Skupiłem się na okresie przed- i pobiałogórskim, czyli chcę słowami Jana Amosa Komeńskiego jako naocznego świadka tamtych wydarzeń pokazać, jak żyło się w Czechach ewangelikom za Rudolfa i Maksymiliana II oraz jaki los spotkał naród czeski w początkowej fazie hegemonii Habsburgów podczas wojny trzydziestoletniej. Jest to próba ujęcia aspektów komeniologii z punktu widzenia historycznego postrzegania ważnych wydarzeń dziejów Czech w ujęciu i myśleniu koncepcyjnym Jana Amosa Komeńskiego. Tekst, oprócz wymiaru historycznego, ma również wymiar społeczny i teologiczny. Dzięki temu interdyscyplinarnemu tłumaczeniu, polski czytelnik ma lepszą możliwość zrozumienia trudnych czasami dylematów, jakie przeżywał naród czeski w tamtym okresie. W niektórych przypadkach konkretne wydarzenia mogą wydawać się dyskusyjne, a nawet kontrowersyjne, lecz takie świadectwo zostało spisane, by dalsze pokolenia wiedziały, jaki był prawdziwy los czeskich ewangelików.
\end{abstract}

Słowa klucze: Komeński i czeski naród, dziedzictwo kulturowe i historyczne, okres przed i po Białej Górze, Habsburgowie i losy Czechów, fakty historyczne

Abstract: This article focuses on the book by Jan Amos Komensky titled The Story of the Heavy Injury of the Czech Church in the 21st Century Language, which was written in the modern language of the 21st century (not seventeenth-century customs, which definitely facilitates reception and better understanding Old-Bohemian literary texts). To better understand the work of the "teacher of nations", I decided to translate two chapters selectively for a Polish-speaking 
reader. I focused on the period before and after White Mountain, i.e. I would like to say, in the words of Jan Amos Komenský, as an eyewitness of those events, how the Czechs lived for evangelicals for Rudolf and Maximilian II and what happened to the Czech nation in the early stages of Habsburg hegemony during the Thirty Years' War. It is an attempt to capture aspects that go towards comeniology from the point of view of the historical perception of important events in the history of the Czech Republic in the conception and conceptual thinking of Jan Amos Comenius. In addition to historical threads, the text also shows the social and theological dimension. Thanks to this interdisciplinary translation, the Polish reader has a better understanding of the sometimes difficult dilemmas that the Czech nation was experiencing at that time. In some cases, specific events may seem controversial, but debatable, but such a testimony was written so that future generations know the fate of Czech evangelists.

Keywords: Comenius and the Czech nation, cultural and historical heritage, the period before and after White Mountain, the Habsburgs and the fate of the Czechs, historical facts

Zagadnienia komeniologiczne są we współczesnych czasach bardzo istotnymi kwestiami, zwłaszcza z punktu widzenia interdyscyplinarnych badań, skoncentrowanych wokół dyscyplin naukowych, jakimi są np. teologia, filozofia, historia, pedagogika, językoznawstwo i literaturoznawstwo wraz z elementami tekstologii oraz z szeroko zakrojonymi analitycznymi, syntetycznymi i empirycznymi interpretacjami. Jak słusznie zauważa prof. Barbara Sitarska, „Komeńskiego poznajemy coraz lepiej, ale pozostaje jeszcze wiele do zrobienia w prawie wszystkich krajach i językach europejskich" (Sitarska 2018: 242). Idąc tym śladem, chciałbym przyczynić się nie tylko do właściwej recepcji dotyczącej twórczości i osobowości Jana Amosa Komeńskiego zwłaszcza w Polsce, ale i poprawnego odczytania jego ważnych myśli i wzniosłych przemyśleń przeznaczonych dla przyszłych pokoleń, które mogą się czasami wydawać z punktu widzenia współczesnego odbiorcy polemiczne, niekiedy aż kontrowersyjne. Da się jednak z dużą dozą prawdopodobieństwa zauważyć, że w jego tłumaczonych dziełach prezentowane są coraz to lepsze i sprawniejsze odzwierciedlenia idei siedemnastowiecznego humanisty baroku europejskiego - w przypadku Komeńskiego baroku emigracyjnego (por. Lehár, Stich, Janáčková, Holý, 2004: 125-148).

Niedawno na rynku wydawniczym, skoncentrowanym przede wszystkim wokół zagadnień literatury czeskiej, pojawiło się jedno ze słynnych dzieł Jana Amosa Komeńskiego. Warto jednak wyraźnie nadmienić, że nie zostało ono zaprezentowane $\mathrm{w}$ oryginalnym, tj. siedemnastowiecznym staroczeskim języku, ale w wersji zmodyfikowanej, uwspółcześnionej czeszczyzny XXI wieku. To nowatorskie z punktu widzenia translatoryki przedsięwzięcie ułatwi zdecydowanie czeskojęzycznym czytelnikom - a nie tylko specjalistom w sposób pełniejszy i dogłębniejszy zrozumienie szeroko pojętej myśli kome- 
niologicznej, toczących się polemik, dyskusji, różnorodnych dylematów i zagadnień ukazanych na tle ówczesnych kontekstów sytuacyjnych, które pragnął najsłynniejszy „nauczyciel nauczycieli” przekazać następnym pokoleniom w sposób obiektywny. Jako bezpośredni świadek tragicznych wydarzeń dotyczących narodu czeskiego, to jest bitwy na Białej Górze, prezentuje on również dalsze losy Kościoła Jedności Braterskiej, które były dla niego bardzo istotnym wezwaniem i życiowym credo.

Komeński, jako osoba głęboko wierząca, podkreślał, że siła nadziei Ewangelii była zawsze przypomnieniem, że Bóg jest suwerennym, absolutnym, niezależnym i najwyższym władcą. Jego osobistą wędrówkę przez „bezbożny świat" trzeba mieć nieustannie przed oczyma, gdyż jest w niej pokazany obraz historycznego postępowania Kościoła. To był właśnie jeden z powodów, dla którego Komeński przy współpracy ze swoimi braćmi ${ }^{1}$ napisał tę książkę, by zachęcić nas i przyszłe pokolenia do wiary w Jezusa Chrystusa. Ciężkie prześladowania po Białej Górze prowadzone przez Habsburgów pokazały świadectwo dotyczące Bożej wierności i wytrwałości niektórych czeskich świętych i męczenników. Komeński powtarzał myśl, która może stać się mottem naszych rozważań: Kościele czeski - trzymaj się wiernie Pisma Świętego, a Chrystus będzie trzymał Ciebie. Niech nas do wierności wzmocni przykład czeskich męczenników.

Powołać się tutaj można bez najmniejszego zastanowienia czy wątpienia np. na Mistrza Jana Husa czy Hieronima Praskiego², którzy byli moralnymi autorytetami dla Komeńskiego (patrz rozdz. VIII opisywanego dzieła), względnie na czeskiego kaznodzieję i radykalnego przedstawiciela husytów Jana Żelivskiego (rozdz. XV) czy przypomnieć o spaleniu Mikołaja Vřetenářa i jego gospodyni Klary (rozdz. XXX) lub o spaleniu Marty z Poříčí (rozdz. XXI), ale warto w tym miejscu również przytoczyć istotną część rozprawy Komeńskiego, czyli np. opis tzw. Czeskiej Golgoty, tj. egzekucji 27 uczestników ruchu

\footnotetext{
1 Chodzi o naocznych świadków, najczęściej pochodzących z Jedności Braci Czeskich, lub o jej zwolenników czy sympatyków, których było naturalnie wielu, zwłaszcza wśród inteligencji. W obszernym wstępie analizowanego dzieła pt. Historie o těžkých protivenstvích církve české vjazyce 21. století, słynny Jan Amos Komeński dołączył dla czytelnika (również obcojęzycznego) przegląd czeskiej historii religijnej. Jest to w pewnym sensie nawiązanie do czołowego pisarza Jedności, brata Jafety (zmarł on w 1614 roku), a także do tzw. Historia Fratrum, napisanej najprawdopodobniej przez sekretarza Blahoslava, brata Wawrzyńca Orlika (zmarł 21.04.1589 roku). Warto zaznaczyć, że nie były to stricte prace naukowe, lecz spis starszych zapisków, sporządzonych w duchu ówczesnych czasów.

2 Hieronim z Pragi [czes. Jeroným Pražský - Hieronymus Pragen] (urodzony około 1378 roku w Pradze, zmarł 30 maja 1416 roku w Konstancji) - czeski teolog, filozof, myśliciel religijny, zwolennik husytyzmu i wiklefizmu, bohater wiary Kościołów protestanckich, spalony na stosie przed 603 laty, podobnie jak Mistrz Jan Hus. Szersze rozważania patrz Nedvědová, Graus 1953.
} 
przeciwhabsburskiego, którzy 21 czerwca 1621 roku na rynku Starego Miasta przed ratuszem staromiejskim w Pradze zostali straceni (patrz rozdz. LX-LXXXII). Właśnie im Komeński poświęca spore fragmenty przedstawianego dzieła ${ }^{3}$. Tym 27 bohaterom, o których to losach i ich ostatnich chwilach życia ziemskiego zdążył spisać wspomnienia dla przyszłych pokoleń wielostronnie utalentowany Jan Amos Komeński, zostanie poświęcony odrębny artykuł w komeniologicznym periodyku naukowym. Szersze rozważania por. Vrabec 1908, Wandycz 1995, Kratochvíl 1975, Kadlec 1991, Herain i Teige 1904, Petráň 1972, 2004, Purš i Kropilák 1982, Svátek 2005, Molnár 1882, Herben $1921 \mathrm{i}$ in..

W przedstawianym dziele Jan Amos Komeński zwraca uwagę na uciemiężenie czeskich niekatolików w okresie panowania Ferdynanda I (patrz rozdz. XXXIV-XXXVII), następnie przypomina przyjście do Czech jezuitów (rozdz. XXXVIII).

W ostatnich rozdziałach (XCII-CII) omawianego dzieła Komeński pisze, jak wyglądała reformacja w wielu regionach Czech, czyli np. w Pradze, Kutnej Górze, Bolesławiu, Litomierzycach, Hradcu Królowej, Bydżowie, Żatcu, Domażlicach, Rokycanach, Slanym, Prachacicach.

W niniejszym artykule pokazane zostaną przykłady (na podstawie relacji Jana Amosa Komeńskiego), jak żyło się czeskim ewangelikom za Rudolfa i Maksymiliana II oraz co się z nimi stało zaraz po tragicznym roku 1620, kiedy w Czechach nastał tzw. okres mroku - czes. doba temna. Zaprezentowany polskojęzyczny tekst jest tłumaczeniem dwóch wybranych rozdziałów $(\mathrm{XL} \mathrm{i} \mathrm{CV})^{4} \mathrm{z}$ książki pt. Historie o těžkých protivenstvích církve české. Vjazyce 21. století - dosł. pol. tłum. Historia o ciężkich krzywdach Kościoła czeskiego w języku XXI wieku. Dzięki temu interdyscyplinarnemu tłumaczeniu spisanemu przez Komeńskiego, polski czytelnik będzie miał możliwość zrozumienia trudnych czasami dylematów, jakie przeżywał naród czeski w początkowym okresie hegemonii Habsburgów, kiedy toczyła się wojna trzydziestoletnia.

\footnotetext{
${ }^{3}$ Byli to następujący czescy męczennicy: Jáchym Ondřej Šlik, Václav Budovec z Budova, Kryštof Harant z Polžic, Kašpar Kaplír ze Sulevic, Prokop Dvořecký z Olbramovic, Bedřich (pol. Fridrich) z Bílé a na Řehlovicích, Oldřich Otta z Losu, Diviš Černín z Chudenic, Vilém St. Konecchlumský, Bohuslav z Michalovic a na Rvenicích, dr Valentin Kochan z Prachové, Tobiáš Štefek z Koloděj, Kryštof St. Kober z Kobersberku, Jan St. Šultys z Felsdorfu, Maxilián Hoštálek z Javořic, dr Jan Jesenský, Dr Jiř́ Hauenschild z Fürstenfeldu, dr Leonhard Rüppel z Ruppachu, Jan Kutnauer ze Sonnenštejna, Simeon Sušický ze Sonnenštejna, Nathanel Vodňanský z Urašova, Václav Maštěřovský z Jizbice, Jindřich Kozel z Peclinovce, Ondřej Kocour z Votína, Jiřŕ Řečický, Michal Wittmann, Šimon Vokáč z Chýš a Spitzberku.

4 Tłumaczone na język polski rozdziały pozostawiam wnumeracji rzymskiej, tak jak w przypadku pierwodruku (tekstu źródłowego).
} 
W niektórych nawet przypadkach pewne wydarzenia mogą wydawać się dyskusyjne, a nawet kontrowersyjne, lecz takie świadectwo zostało spisane, by dalsze pokolenia wiedziały, jaki był los czeskich ewangelików.

W punkcie pierwszym XL rozdziału Jan Amos Komeński stara się w sposób rzetelny i obiektywny przedstawić działania, jakie były podejmowane w stosunku do narodu czeskiego przez Maksymiliana II Habsburskiego i jego syna Rudolfa. Następnie koncentruje się na intrygach jezuitów oraz zwraca uwagę na słynne rozporządzenie Władysława ${ }^{5}$. Pisze też o Pikardach ${ }^{6}$, które to słowo miało negatywne konotacje, a także nadmienia o dosyć ważnym fakcie historycznym, czyli zagarnięciu Belgradu przez Turków. W drugim punkcie tego samego rozdziału skupia się na ważnym dokumencie - Majesta$\mathrm{cie}^{7}$. W trzecim punkcie opisuje konsystorz i jego skład oraz jak działała kompaktata ${ }^{8}$. W czwartym punkcie przedstawia, jak stany ziemskie pod dwoma i jedną postacią zjednoczyły się. W piątym punkcie prezentuje w ujęciu alegorycznym sytuację, jak w czasie pokoju spotkały naród czeski wichury ferdynandowskie, czyli według słów Komeńskiego (2018: 77) - jak w czasie pokoju może smakować najbardziej gorzka gorycz.

\footnotetext{
${ }^{5}$ Rozporządzenie Władysława zostało wydane podczas panowania Władysława II Jagiellończyka (1456-1516) i określane jest jako wyraz słabości panującego monarchy, ponieważ doprowadziło do znaczącego ograniczenia królewskiej władzy. Była to tzw. Ustawa Krajowa Królestwa Czeskiego, pierwsza kodyfikacja prawa. Szlachta uzyskała uprzywilejowaną pozycję w Królestwie Czeskim kosztem władcy i mieszczaństwa.

${ }^{6}$ Pikardowie (łac.: Pikarti, Picardi) - to grupa religijna, chrześcijańska z XIV-XV wieku, działająca w Europie zachodniej i w Czechach. Z punktu widzenia historyczno-religijnego - jak podkreśla NASCS 2007: 620 - chodziło o świeckich (tzw. laickich) członków wspólnoty w Picardii we Francji. Grupę tę uważano często za heretycką wspólnotę, mającą wpływ na początkową działalność ruchu husyckiego. W przenośnym znaczeniu tego słowa, zwłaszcza z perspektywy katolików, chodziło o reprezentanta różnych sekt heretyckich w średniowieczu. Przedmiotowy leksem pikard wskazywał na 'heretyka'.

7 Majestat (zazwyczaj znany jest pod nazwą Majestat Rudolfa lub list majestatyczny) był dokumentem wydanym przez Rudolfa II 9 lipca 1609 roku. Akt ten zapewniał wolność religijną w Królestwie Czeskim. Jednocześnie potwierdzał czeską konfesję, którą jego ojciec Maksymilian II obiecał tylko ustnie, a miało to miejsce w 1575 roku. Według Majestatu nikt nie mógł być zmuszany do wyznania katolickiego lub innego. Obowiązywał dla miast królewskich, szlachty i poddanych. Akt ten został wpisany do ksiąg ziemskich jako obowiązujące prawo i nabrał mocy prawnej. Jak zaznacza Joanna Brodniewicz (2016: 16), list majestatyczny zezwalał na confessio bohemica - przyjęcie wspólnego wyznania wiary przez luteranów i braci czeskich. Był to jednak na długi czas ostatni znak wolności religijnej.

8 Kompaktata (łac. com 'współ i pactum 'umowa') - ugoda zawarta przez Sejm Królestwa Czeskiego z reprezentantami Soboru Bazylejskiego, dotycząca warunków pokoju i ustępstw Kościoła katolickiego na rzecz czeskich husytów. Główne założenia kompaktaty koncentrowały się na autonomii Kościoła husyckiego, na przyjmowaniu komunii pod obiema postaciami (chleba i wina), na możliwości przeprowadzania liturgii w języku czeskim (ti. ojczystym) oraz na wyborze arcybiskupa praskiego przez Sejm czeski.
} 
Po dokładnym przeanalizowaniu poszczególnych fragmentów (również tłumaczonego rozdziału - patrz aneks nr 1 na końcu artykułu), można wysnuć wniosek, że Komeński sporządza pewnego rodzaju praktyczny podręcznik historyczny. Jak konstatują Mirosław i Věra Hrohowie (1959: 417), badania komeniologiczne przestały być głównie domeną pedagogów. Można nawet stwierdzić, że zachodzi tu odchylenie w stronę przeciwną. Toteż powoli zaczynają zanikać typy komeniologów specjalistów, zajmujących się wąskimi zagadnieniami z dzieł mistrza ${ }^{9}$. Rozszerzają się horyzonty, wzbogaca się materiał faktograficzny, co jest wynikiem rozwijającej się współpracy uczonych $\mathrm{z}$ różnych dziedzin wiedzy. Idąc tym tropem, przedstawiam rys historycznego ujęcia konkretnych wydarzeń mających bezpośredni związek zhistorią Kościoła i władzą Habsburgów, spisanych w dziele, jakie pozostawił nam Jan Amos Komeński.

Przetłumaczony kolejny fragment, czyli rozdział CV, składa się z jedenastu podrozdziałów, w których Komeński najpierw opisuje pokazane Janowi królestwo antychrysta, które porównuje ze współczesnymi jemu niełatwymi czasami, kiedy kościoły, obrazy, groby oraz kości pogrzebanych były haniebnie dewastowane i profanowane (patrz punkt pierwszy). W drugim punkcie Komeński cytuje fragment z nowotestamentowego Pierwszego listu do Tymoteusza, przywołując Ducha Świętego, modlitwę i wodę święconą. Później opisuje, jak jezuici rozsypywali w kościołach proch strzelniczy, który następnie podpalali, by przepędzić z nich herezję. Postępowano tak w Pradze, Jihlavie i Znojmie. W trzecim punkcie eksponuje Komeński ważny znak (tzw. symbol ujmowany jako kulturem) w postaci kielicha. Por., jak znieważano kielich w różnych miastach Czech (Praga, Hradec Králové, Litoměřice). Komeński zwraca również uwagę na język nienawiści. Podaje przykład, że nad drzwiami kościoła św. Antoniego w Hradcu Královém napisano złotymi literami piękne przysłowie [z niepiękną po myślniku modyfikacją - uwagi L.H.]: Mój dom jest domem modlitwy - a nie twoim, brudny Kalwinie (Komeński 2018: 200). W czwartym punkcie przedstawia los, jaki czekały heretyckie wydania Biblii, przywołując jednocześnie dwa fragmenty Pisma Świętego, pochodzące ze Starego Testamentu (por. 1 Mch 1,59 i Jr 36,23). Przytacza sytuacje niegodnego traktowania „księgi ksiąg”, czyli Biblii, jakie miały miejsce w Nachodzie, Fulneku, Żatcu, Trutnowie, Hradcu itp. W piątym punkcie Komeński najpierw przywołuje mądre powiedzenie Owidiusza, w którym

\footnotetext{
9 Wyjątkowość osobowości J.A. Komeńskiego polega między innymi na jego wielostronności znajdującej odbicie zarówno w szeroko zakrojonej działalności, jak i w różnorodności jego dzieł (por. Bečková 1979: 3).
} 
wyeksponowano trzech przedstawicieli świata zwierzęcego, zaliczanych do groźnych drapieżników (lew, wilk i niedźwiedź). Następnie opisuje, jak w 1621 roku w Horażdżowicach bezczeszczono groby księży (np. Jakuba Wielkiego, Jana Popela, Jana Jaffety i Macieja Chobara, Theobalda Švihovskiego, defensora konsystorza i uniwersytetu). W szóstym rozdziale Komeński opisuje, jak w 1623 roku zabrano ewangelikom w miejscowości Čáslav kościół, w którym spoczywał od 1424 roku Jan Žiška z Kalicha. Jego grób sprofanowano i ogołocono do zera. W siódmym punkcie przedstawiono sytuację z Pragi, jak Jan z Rokycan ${ }^{10}$ musiał po 159 latach i 7 miesiącach (zmarł 21 lutego 1471) pozostawić swój grób innemu zmarłemu (jezuicie Łukaszowi). Ósmy punkt poświęcono cmentarzowi w Trzebowej na Morawach. Dziewiąty punkt koncentruje się na opisie, co przydarzyło się pobożnemu mężczyźnie Janowi Mathiadowi, kaznodziei u św. Barbary w Kutnej Górze, który w 1625 roku (kiedy potajemnie wrócił z wygnania) zmarł w swoim domu. Komeński także przedstawia sytuację, jaka spotkała księgarza Adama Hovorkę. W dziesiątym punkcie Komeński przywołuje słowa Semiramidy ${ }^{11}$ (Semiramis), która pozwoliła napisać na swojej trumnie następujące motto: Kiedy nie byłbyś bezbożnym człowiekiem, martwym byś nie przeszkadzał (Komeński 2018: 203). Ma to bezpośrednie przeniesienie na zaistniałą sytuację pobiałogórską (profanowanie grobów niekatolickich przez Habsburgów, z przyzwoleniem Kościoła katolickiego). Radzi, by ten napis nosili na czołach bezbożni i niemoralni ludzie, którzy zniżają się do tak haniebnych czynów. Jedenasty punkt mówi o tym, w jaki sposób przejawiają oni swoją wściekłość na samo brzmienie imienia Fridrich (z nienawiści do pobożnego króla, który zezwalał na przyjmowanie komunii pod dwoma postaciami). Przykład dotyczy mistrza Jana Libertina, mieszczanina z Nowego Miasta Praskiego, który dał w 1620 roku swojemu synowi na imię Fridrich. Za to został ukarany grzywną 500 talarów.

Jak konstatuje Bartoš (2018: 10), Komeński w swoich przemyśleniach w sposób szczególny zwraca się do narodu czeskiego. Sytuację, w jakiej musiał żyć (jeszcze na terytorium Czech - przed przymusową emigracją), porównuje z przejściem wichur gniewu Bożego, które są przez niego (patrz konkretnie analizowane rozdziały monografii) drobiazgowo opisywane. Głęboko wierzył, że utracona władza zostanie ponownie oddana narodowi.

\footnotetext{
10 Czeski duchowny i kaznodzieja, teolog husycki, utrakwista (kalikstyn), rektor Uniwersytetu Karola i arcybiskup Pragi.

11 Znana jest z tradycji hellenistycznej i antycznej. Chodzi o legendarną królową babilońską, bohaterkę licznych podań i legendarnych opowieści z terenów Bliskiego Wschodu.
} 
Zastanawiając się nad konceptualnymi rozważaniami komeniologicznymi, na ogół prawie wszyscy kojarzą Jana Amosa Komeńskiego z dziełami naukowymi, głównie z zakresu pedagogiki czy filozofii, natomiast niniejsze dzieło (a ściślej ujmując przedstawiany wybiórczo tekst) ma zupełnie inny wymiar, ponieważ koncentruje się ono na teologiczno-społecznych przesłankach $^{12}$ oraz na istotnych faktach historycznych. Te wzmiankowane wątki (zwłaszcza historyczne) przyczyniają się do szerszego postrzegania perspektywy rozwoju komeniologii ${ }^{13}$. Historię i istotne losy swojego narodu - na co zwraca uwagę Komeński - powinien odpowiednio znać każdy jego członek i właśnie próbę takiego ujęcia dostrzegamy w przedstawianym dziele. Bierzemy pod uwagę także fakt, że taki podręcznik w owych czasach (kiedy żył Komeński w Czechach) nie mógł być bezpośrednio wydany z powodu hegemonii Habsburgów.

Komeński jako nauczyciel (również historii) zwraca uwagę na istotne wydarzenia historyczne, które miały swoje epokowe miejsca do siedemnastego wieku i zarazem kształtowały także w pewnym stopniu rozwój Czech w Europie. Takie terminy (por. np. rozporządzenie Władysława, Pikardowie, Majestat, konsystorz, kompaktata, stany ziemskie, wichury ferdynandowskie, miecz i kielich, Biblia, husytyzm, Jedność Braci Czeskich, Uniwersytet), które istniały i spełniały określone funkcje, powinien znać każdy mieszkaniec swojego państwa, z którym się identyfikuje i utożsamia. To właśnie przedstawione historyczno-kulturowe dziedzictwo chciał przekazać Komeński przyszłym pokoleniom.

\footnotetext{
12 Niniejsze dzieło Jana Amosa Komeńskiego można by spróbować dołączyć zarówno do ezoterycznego gatunku literackiego, jako nauki duchowej, ale także i do ogólnie pojmowanego popularnonaukowego stylu. Przedstawiana ezoteryka związana jest z pojęciem religii, którą można podzielić na część zewnętrzną (praktyki kultu, obrzędy, przykazania, prawa i podstawowe zasady) i wewnętrzną (ukrytą, zamkniętą wiedzę i zbiór praktyk). Chodzi o pokazanie analizy swojego życia, czyli rozwój wewnętrznej wiedzy człowieka w relacji z otaczającym światem oraz znoszenie przeciwności i wszelakich trudów z godnością, o czym właśnie pisze Komeński.

13 Te wybiórczo przetłumaczone w całości dwa rozdziały (XL i CV), które wyszły spod pióra Jana Amosa Komeńskiego, powinny przybliżyć współczesnemu polskojęzycznemu czytelnikowi ówczesną sytuację, jaka panowała w Czechach w okresie przed-i pobiałogórskim. Z tą rzeczywiście niełatwą sytuacją musieli zmierzyć się wyznawcy husycyzmu i zwolennicy Jedności Braci Czeskich, którego jednym z przedstawicieli był właśnie nasz siedemnastowieczny bohater. Z powodu prześladowań religijnych (por. reformacja i kontrreformacja) musiał on opuścić swoją ukochaną ojczyznę, do której już nigdy nie pozwolono mu powrócić. W takich czasach musial żyć, działać i twórczo pracować Jan Amos Komeński, którego cały świat uznaje za autorytet w dziedzinie oświatowo-dydaktycznych koncepcji nauczania oraz uważa go również za prekursora w kwestiach pansoficznych dotyczących naprawy świata. Uznawać go także trzeba za historyka, który troszczy się o to, by przyszłe pokolenia poznały dzieje swojego narodu.
} 
Zaś Petr Pavlas (2015: 168) analizując księgi Komeńskiego zaznacza, że jego myślenie jest kompleksowe, uwzględniające całość zagadnienia, spełnia ono wymogi integralności, a zaprezentowane przykłady są oryginalne i źródłowe, odzwierciedlające ważne czeskie wydarzenia historyczne, co poszerza szeroko pojmowany temat i obszary istotnych aspektów komenio$\operatorname{logii}{ }^{14}$.

\section{ANEKS NR 1 - ROZDZIAŁ XL15}

\section{Za panowania Rudolfa odzyskali ewangelicy zupełną wolność}

1. W następnym okresie periodycznym, czyli w 1575 roku pańskiego szlachetny Maksymilian II Habsburski został wyrwany z tego świata i po nim królował jego syn Rudolf. Aż do roku 1602 kroczył on po wydeptanych ścieżkach ojca i nie pozwolił, żeby ktoś mógł być skrzywdzony z powodu kwestii wyznaniowych lub religijnych. Dopiero w tym roku za sprawą intryg spowodowanych przez jezuitów doszło do tego, że podpisał i w końcu nakazał wydanie spisanego przez nich rozporządzenia, dzięki któremu ponownie przywrócił pierwotną moc nakazu Władysława. Ale przez ten czyn nie osiągnięto wiele, oprócz tego, że zamknięto kilka zborów braterskich. Czołowi przywódcy braci przeciwko takiemu działaniu zaprotestowali i bronili się, że postanowienie to ich nie dotyczy, ponieważ wcale nie są takimi, jak pikardowie, opisywani w przedmiotowym rozporządzeniu. Łatwo osiągnęli taki stan rzeczy, że spokojny cesarz nawet lekko znosił sytuację, kiedy jego zarządzenie nie było dokładnie dotrzymywane. Nawet nieprzyjaciele innych stanów ewangelicznych nie mogli się przeciwko nim postawić. Wiarygodni ludzie twierdzili, że wieczorem tego dnia (22 lipca), kiedy do cesarza dotarła wiadomość, że Turcy wzięli w posiadanie królewski Belgrad, istotną miejscowość wśród węgierskich miast, cesarz się przeraził i powiedział: „Od razu bałem się, że coś się stanie, kiedy dziś zacząłem brać w swoje ręce władzę dotyczącą sumienia i świadomości ludzkiej, która należy tylko do Boga". Była to niewątpliwie aluzja do wcześniej wymienionych słów jego ojca, które utkwiły mu głęboko w pamięci.

14 Zwieńczeniem tych starań jest polskojęzyczne tłumaczenie dwóch rozdziałów w postaci aneksu nr 1 i 2.

15 Dotyczy str. 74-77 tekstu oryginalnego w zmodyfikowanej wersji (Makovička, Kostelník 2018) uwspółcześnionego języka czeskiego XXI wieku. 
2. Później wyraźnie wyjaśnił, że nie chodziło mu o nic innego, niż tylko o to, by spełniły się obietnice swojego pobożnego ojca i jednocześnie by umocniła się wolność sumienia. W1609 roku przeciwko woli papieża i kompanii hiszpańskiej, a nawet i nie jednego ze swoich osobistych doradców, oddał stanom ziemskim pod dwoma postaciami dolny konsystorz z Uniwersytetem, by je według swojego przekonania odnowić. Dołączył do tego tzw. Majestat, w którym wszystko im potwierdził, a także pozwolił im, by dalej byli właścicielami szkół i kościołów, które już posiadali wcześniej, a jeżeli zajdzie nawet taka potrzeba, by mogli budować nowe. Również wszystkim zakazał prześladować kogokolwiek z przyczyn religijnych (dotyczyło to wszystkich, czyli i jego ludzi, i ludzi z otoczenia papieża, duchownych i poddaństwa) oraz zobowiązał przyszłych króli i swoich następców, by o to wszystko dbali. Oprócz tego dał stanom pełnomocnictwo do powołania ze swojego grona strażnika i obrońcę tej wolności.

3. Stany odnowiły więc konsystorz, a żeby wzmocnić jedność, wybrały do niego podczas głosowania trzech husytów, trzech braci, trzech księży z reszty ewangelików oraz dołączono do nich również trzech profesorów uniwersyteckich. Tym dwunastu wybranym mężczyznom oddano pod opiekę wszystkie sprawy kościelne całego królestwa. Ponieważ wszyscy już zgodzili się co do tego, że zlikwidują kompaktatę, i że wszystkie Kościoły będą kierować się prawdą samego słowa Bożego, został wybrany pierwszy administrator, czyli K. Eliasz Šud ze Semanína16, pochodzący z szeregów husytów. Każda następna osoba miała być wybierana ze wspólnego zgromadzenia księży. Braciom pozwolono działać (postępować) według ich własnych reguł, wewnętrznie obowiązujących zasad i regulaminów aż do czasów jakiegoś lepszego w przyszłości uporządkowania. Zostało to uzgodnione w taki sposób, że póki będą istnieć różnice w zakonie (lecz w przyjacielskiej jednomyślności), będą mieć prawo do posiadania seniora ze swoich szeregów, który będzie jednocześnie najbliższym współpracownikiem administratora. Uniwersytet - jako swoim własnym potomkom Husa - wypożyczył im w Pradze Kaplicę Betlejemską, słynną z doskonałych kazań Mistrza Jana Husa. Wszyscy pobożni ludzie z tych przeprowadzonych działań radowali się, wychwalali Pana Boga, a na różnych miejscach w kościołach pisali wiersze w języku łacińskim:

\footnotetext{
16 Funkcję administratora konsystorza pełnił do 29 maja 1614 roku, kiedy śmiertelna choroba, jaką była dżuma, go pokonała. Więcej informacji na: https://historie-semanin.webnode.cz/ kapitoly/a7-elias-sud/ (dostęp 21.08.2019).
} 
Templa patent, Leo laetus ovat, firmante Rudolpho, Quam dederas Fidei Maxmiliane fidem

co oznacza:

Kościoły otwarte,
Czesi rozweseleni,
co Maksymilian obiecał,
to Rudolf spełnił.

4. Stany ziemskie pod dwoma i jedną postacią zjednoczyły się i zawarły między sobą przyjacielski traktat o zachowaniu pokoju, zgody, jednomyślności i spójności, które zostały wyrażone za pomocą konkretnych zapisów, następnie włożono je do ksiąg ziemskich i zatwierdzono podpisem cesarza i jego doradców. Znalazły się trzy osoby, które nie chciały podpisać się za pierwszym, drugim ani trzecim razem, mówiąc, że sumienie ${ }^{17}$ im na to nie pozwala. Są to: Zdeněk Vojtěch Popel z Lobkovic najwyższy kanclerz Królestwa Czeskiego, Vilém Slatava z Chlumu a z Košmberka oraz Jaroslav Bořita z Martinic nazywany Smečanský. Z powodu nich (tj. ich protestu) stany pod dwoma postaciami dopisały do traktatu ważny zapis uzupełniający: jeżeli by kiedyś w przyszłości ktoś szukał pretekstu, jak naruszyć wolność, którą cesarz pożyczył stanom (a ci ludzie przez swoje niepodpisanie się udowadniają, że mają podobne zamysły), będzie się z nimi postępować jako z naruszycielami ogólnego pokoju. Dodatek ten za zgodą Rudolfa został również zapisany do ksiąg ziemskich, umiejscowiony został wśród przywilejów, a razem ze wszystkimi pozostałymi przywilejami potwierdzony został przysięgami zastępców Rudolfa.

5. W ten sposób w całym Królestwie rozkwitła czysta wiara, a fałszywy husytyzm powoli zniknął. Z biedą znalazłby się chociaż jeden ze stu, który by nie identyfikował się z wiarą ewangelicką. Lecz Biada! Do wolności religijnej - jak to już bywa - wkradła się samowola (czyli nieposłuszeństwo wraz ze swawolą), a nawet i ci, którzy wcześniej zachowywali pobożną dyscyplinę wyznaniowo-religijną, w wielkiej mierze od niej odchodzili. Taki rodzaj wolności i cielesnego bezpieczeństwa zdecydowanie nie podobał się wszystkim pobożnym (tj. religijnym) ludziom, a niektórzy od samego

\footnotetext{
17 Por. współcześnie używane określenie, znane jako tzw. klauzula sumienia - uwagi własne L.H.
} 
początku mieli złe przeczucia - aż w końcu dopadły nas wichury ferdynandskie i napełnił się ów proroczy głos, który mówi: „W czasie pokoju spotkała mnie najbardziej gorzka gorzkość". Więcej o tych kwestiach w następnych rozdziałach.

\section{ANEKS NR 2 - ROZDZIAŁ CV18}

\section{Z jaką wściekłością obchodzili się nieprzyjaciele z kościołami, książkami i z martwymi ludźmi}

1. Ufamy, że kiedy świętemu Janowi zostało pokazane królestwo antychrysta w postaci drapieżnika ${ }^{19}$, miało to swoją dobrą przyczynę. Tę samą rzecz możemy widzieć własnymi oczami, kiedy popatrzymy, jak ta bestia szorstko postępowała z żywymi i martwymi i jak ona ze wściekłością niszczyła wszystko, co napotkała na swojej drodze. Pokażemy więc sobie, jakimi sposobami wylewała sobie złość włącznie z odczuwaną wściekłością na rzeczach materialnych, jakimi są np. kościoły, księgi, ambony, obrazy, groby oraz kości pogrzebane.

2. Odnośnie do kościołów - nie trzeba nadmiernie przypominać - że wodą święconą oczyszcza się je od herezji (co jest zabobonem z przyzwyczajenia dla tych wszystkich, którym nie wystarcza poświęcanie wszystkiego przez wiarę i modlitwę, tak jak o tym uczy Duch Święty chrześcijan w nowotestamentowym Pierwszym liście do Tymoteusza - patrz $1 \mathrm{Tm}$ $4,5)^{20}$. Koło ambon w kościołach, z których kazano Słowo Boże oraz koło ołtarzy, na których sprawowano najświętsze sakramenty pod dwoma postaciami, majtali miotłami i głośno trzaskali, strzelając z bicza, tak jakby zwariowali - co było dla prostych ludzi śmieszne, a dla tych mądrzejszych stało się to pretekstem do trującej nienawiści wobec Słowa Bożego. Tak głupio postępowano przede wszystkim wznaczących miastach, czyli w Pradze, Jihlavie i w Znojmie.

W Pradze jezuici chcieli wyczyścić i ponownie poświęcić swój kościół, ponieważ za panowania Fridricha był on wypożyczony przez braci. Rozsypali w nim wtedy proch strzelniczy, ten następnie podpalili, a przez wydobywające się płomienie i dym z niego przepędzali herezję.

18 Dotyczy str. 199-203 tekstu oryginalnego w zmodyfikowanej wersji (Makovička, Kostelník 2018) uwspółcześnionego języka czeskiego XXI wieku.

19 Niektórzy tłumacze używają również innej terminologii, profilując takie leksemy, jak np.: bestia, bestya, bestyja, zwierzę, itp. Komeński pisząc o drapieżniku, w tekście wiodącym ma na myśli Habsburgów i zło wyrządzane przez Kościół katolicki.

20 Por. Staje się bowiem poświęcone przez słowo Boże i przez modlitwę (tłum. BT 1989: 1349). 
3. Na większości czeskich kościołów, miejskich wieżach i na bramach (na pamiątkę tego, że starsi wierni Czesi swoje wyznanie bronili mieczem) znajdowały się kamienne czy miedziane kielichy - te jednak wszystkie zostały zniszczone. W Pradze zdjęto z Tejnskiego kościoła wielki pozłacany kielich (urzeczywistniło się to 23 stycznia 1623 roku), a na jego miejscu zawisł obraz Maryi. Zamiast króla Jerzego z ciosanym mieczem jako symbolem obrońcy kielicha zawieszono obraz Ferdynanda, który z mieczem walczy przeciwko heretykom.

W Hradcu nad bramą kościelną św. Antoniego zamazano kielich, a w jego miejsce namalowano monstrancję i pod nią przewrócony kielich, z którego wylewały się gęste drożdże // (inni pojmują jako fekalia). Pod rysunkiem napisano: Ebiberunt et feces - Wypili i drożdże (lub inna wersja tłumaczenia: spróbowali i kał). Nad samymi drzwiami napisano złotymi literami piękne przysłowie [z niepiękną po myślniku modyfikacją, w języku nienawiści - uwagi L.H.]: „Mój dom jest domem modlitwy - a nie twoim, brudny Kalwinie".

W Litomierzycach zaś wyniesiono z kościoła starodawne obrazy Mistrza Jana Husa i czeskiego Hieronima i podpalono je - przez co ponownie udowodniono, jak okrutnie (tj. Habsburgowie) postępują ze świętymi męczennikami.

4. Jak obchodzili się z książkami, już niewątpliwie wszyscy wiemy z różnych poświadczonych wiadomości i innych dostępnych źródeł. Ci źli ludzie zniszczyli tysiące egzemplarzy Biblii, nie mówiąc również o sporej ilości innych książek. Pomińmy jednak ten fakt w milczeniu. Może i dlatego, by antychryst pokazał, że na pewno nie da się przemóc ani pokonać przez Antiocha (1 Mch 1,59). Ogólnie obowiązywała zasada, że wszystkie książki heretyckie czekał ogień. Jest znany także przypadek, że hrabia z Nachodu, zdrajca i odszczepieniec, który miał swoje święte księgi ozdabiane aksamitem i dekorowane złotem i srebrem (ze względu na to, że żył okazale ponad ogólnie przyjęty stan), sam od siebie ze swoich ksiąg dał najpierw usunąć wszystko złoto i srebro, a dopiero później kazał je wrzucić do szamba.

Różni ludzie zachowywali się różnorodnie. Niektórzy palili księgi zabrane ewangelikom potajemnie w domu jak kiedyś Judi ${ }^{21}$ w starotestamentowej

21 To biblijne nazwisko inni tłumaczą przez leksemy nazw własnych jako: Judi (BJW, BT, BWP, BJ, BPaul), Jehudi (BW, BP, PNŚ, BEk), Jehuda (BG), Jehudja (NBG), Jehudy (BBrz) - czes. Juda (BK), Judi (BO, BČ3), yudy (BD), Jehúdí (ČEP, SNC, PSP), Jehudí (ČSP, PNS), Jehudi (B21, JB). 
Księdze Jeremiasza (patrz werset Jr 36,2322). Inni zaś wynosili je na rynek w koszach (tak jak we Fulneku), inni je (tak jak w Žatcu i w Trutnowie) wywozili na wozach za mury obronne miasta, a jeszcze inni je znów kazali gromadzić pod szubienicą lub koło miejsca kaźni (tak jak w Hradcu), gdzie zbudowano z książek stos, który później podpalono. Uważajcie tylko, by niewinny popiół tych nieżyjących męczenników, który przez was został rozproszony w powietrzu i po ziemi, nie rozniósł jeszcze dalej właśnie tę naukę, którą zniszczyć chcecie.

5. Nieprzyjaciele najwidoczniej zapomnieli o powiedzeniu Owidiusza, że:

Corpora magnanimo satis est prostrasse leoni,

pugna suum finem cum jacet hostis, habet,

at lupus et turpes instant moricntibus ursi etc.

co oznacza

Wielkie ciała zabić

lew przyzwyczaił się dużo mieć.

Kiedy nieprzyjaciel pokonany,

zazwyczaj bój bywa ukończony.

Tylko wilk i niedźwiedź pożądliwy,

nawet i zmarłych udławi.

Tyranie zdecydowali się, że będą naśladować niedźwiedzią i wilczą agresję, więc za wielką sławę uważali i okrutne obchodzenie się z nieżywymi już ludźmi. Jakie musiało to być okropne zezwierzęcenie, że nie mogli ścierpieć żywych na ziemi, ani nie potrafili uszanować martwych pod ziemią! Znalazłoby się sporo przykładów, jak wielu martwych wygrzebano z grobu i ich kości porozrzucano lub spalono.

Kiedy w 1621 roku w Horażdżowicach przejęli mnisi klasztor, który przedtem długo służył Czeskim braciom, zaraz otwarli groby księży tam znajdujące się. Najpierw zbezczeszczono grób Jakuba Wielkiego, mężczyzny wielkiego słowem i uczynkiem, który został pochowany w 1600 roku. Severinus Dudecius, przełożony klasztoru, roztrzaskał jego kości żelaznym młotem na kawałki i przeklął je. Następnie nakazał, by proch wspólnie z kośćmi Jana Popela, Jana Jaffeta i Macieja Chobara, którzy zostali pocho-

22 Por. Gdy Judi przeczytał trzy lub cztery kolumny, odcią je król nożem pisarskim i rzucał do ognia, który był w naczyniu, dopóki cały zwój nie spłoną w ogniu, który był w naczyniu (tłum. BT 1989: 949). 
wani w latach 1599, 1614 i 1616, spalono na cmentarzu. W tym samym kościele pochowani byli i włodarze tegoż miasta, czyli Švihovští (Szwihowscy). Ich groby bezbożny opat również otworzył i z ciał bestialsko zabrał wszystkie pierścienie, łańcuchy oraz inne cenne przedmioty. Na sam koniec wyciągnięto z grobowca ciało Theobalda Švihovskiego, defensora konsystorza i uniwersytetu, później wyjęli go z ocynkowanej trumny, włożyli do drewnianej, a na cmentarzu go w jakimś dołku zasypali gruzem, ponieważ klasztor akurat był w remoncie.

6. W 1623 roku zabrano Ewangelikom w miejscowości Czaslav (czes. Čáslav) kościół, w którym nad jednym grobem znaleźli następującej treści napis: Anno 1424, die Jovis ante festum Galli vita functus est Iohannes Ziska a Calice, Rector Rerum publicarum, laborantium in nomine et pro nomine Dei, hoc loco conditus est (tj. w roku pańskim 1424, w czwartek przed św. Hawlem, wyzionął ducha Jan Žiška z Kalicha, zarządca gmin chrześcijańskich, skupionych wokół imienia Bożego, i tutaj jest pochowany). Zaraz wzięli się do roboty, by szybko wykopać człowieka, który dwieście lat odpoczywał już w grobie. Kopali bardzo głęboko, ale oprócz pyłu niczego nie znaleźli. Obrócili więc swój gniew przeciwko kamieniowi nagrobnemu, na którymś kiedyż był wyryty portret Žišky (ten zamazali już wcześniej). Kamień rozbili, a razem z gruntem znajdującym się w grobie wynieśli z kościoła na zewnątrz i rozmiażdżyli na piasek. W ten sposób pomścili się na martwym, który im w okresie, kiedy żył, spowodował dużo problemów.

7. Tegoż roku, kiedy czyszczono praskie kościoły od pochowanych tutaj heretyków, podniesiono kamień marmurowy, leżący nad grobem Rokycana, który został w całości roztłuczony, lecz samotnego grobu nie znaleziono. Dopiero w roku 1633, kiedy 24 września zmarł jezuita pater (ojciec duchowy) Łukasz, kaznodzieja niniejszego kościoła i miał być pochowany, wykopano mu głęboki grób. Natrafiono wtedy na podłogę z cegieł. Kiedy ją rozebrano, znaleziono spróchniałe kości z dwoma nienaruszonymi kielichami, z których jeden był miedziany, a drugi z wosku. Znajdował się tam kawałek adamaszku, najprawdopodobniej z któryś z szat kapłańskich i czaszka, na której znajdowało się parę rudych włosów. Kości zabrano do kosza i zaniesiono je do kaplicy, gdzie tymczasowo je pozostawiono, póki zwierzchnictwo nie zadecyduje, co z nimi dalej zrobić. Nie wiemy, co się z nimi następnie stało, lecz tą opowieść mamy od naocznych świadków. W ten sposób musiał Jan z Rokycan po 159 latach i 7 miesiącach (zmarł 21 lutego 1471) pozostawić swój grób innemu. 
8. W Trzebowej na Morawach na cmentarzu znajdowało się kilka posągów księży wyżłobionych z kamienia, którym jezuita młotkiem i dłutem wydłubał oczy. W ten sposób sam ślepy oślepiał ślepych.

9. Okrutnie, w sposób bestialski jednak obchodzono się nie tylko z martwymi, lecz i z tymi, którzy mieli być lada moment pochowani. Pominę milczeniem to, że im odmawiano uczciwego pochówku na cmentarzu i zmuszano ich do pochówku na polach, w ogrodach, przy drogach, a nawet i w miejscach egzekucji. A kiedy niektórym zabraniano wynoszenia martwych (nieboszczyków) z domu, by zwrócić ich ziemi, matce wszystkich, to dopiero było przesadzone barbarzyństwo. A to wszystko czyniono tylko dlatego, by pokazać swoją nienawiść do tych, co zmarli w Chrystusie, a żywym odradzano smrodem z trupa wytrwałości przy naśladowaniu prawdy Bożej.

Opiszę, co się przydarzyło pobożnemu mężczyźnie Janowi Mathiadowi, kaznodziei u św. Barbary w Kutnej Górze, który w 1625 roku (kiedy potajemnie wrócił z wygnania) zmarł w swoim domu. Kiedy o tym fakcie dowiedział się arcydziekan Appiau ${ }^{23}$, zabronił go pogrzebać i nie pomogły żadne prośby ani pieniądze. Dopiero po ośmiu dniach jacyś dobrzy ludzie wzięli potajemnie jego ciało i w nocy go w pewnym miejscu pochowali. Ten Belial24 później się wściekł ze złości i wypytywał się, kto to zrobił, nawet i groził odcięciem głowy, ale na nic się to zdało, było to marne. Kiedy po tym wydarzeniu w krótkim okresie czasu tj. 30 października ten sam niegodziwiec ${ }^{25} \mathrm{w}$ podobny sposób chciał sprofanować ciało jakiegoś księgarza Adama Hovorky, ponieważ dał swoje dziecko ochrzcić gdzie indziej, lud znów pokazał podobny przykład miłości, co nie podobało się arcydziekanowi ${ }^{26}$, który prawie nie pękł ze wściekłości, gdyż to było uczynione przeciwko jego woli, z którą czeski lud zdecydowanie nie zgadzał się.

\footnotetext{
23 Winno być czes. arciděkan kněz Matouš Appian z Millesů - [tłum. pol. arcydziekan ks. Mateusz Appian z Millesów] - (powołany na to stanowisko 3 czerwca 1623 roku) (por. Hanuš 2012: 7). ${ }^{24}$ W ST jest synonimem nieprawości, szatana, a w NT jest przeciwnikiem Chrystusa, czyli Antychrystem. Pojawia się w 2 Kor 6,15. Uznawany jest za księcia ciemności, zagorzałego przeciwnika Boga. Określenie zła ('nieużyteczność', 'zniszczenie', 'złośliwość'), a w późniejszym judaizmie szatana // demona. Zapisywany jest w przekładach biblijnych jako Belijał (BG), Belial (BJW, BBrz, BW, BP, PNŚ), Beliar (BT, BWP, NBG, BJ, BPaul, BEk) - czes. Beliál (BK, ČEP, B21), Belial (BO, ČSP), belyal (BD), Beliar (JB, PSP), Belijal (PNS), d'ábel (SNC).

25 Można by było użyć również określeń: podlec, kanalia, drań, łajdak, łotr.

${ }^{26}$ Jest to kapłan mianowany biskupem. Podlegają mu niektóre dekanaty i wikariaty rejonowe. Jest to również honorowy tytuł niektórych proboszczów (por. Kraus 2007: 70) lub honorowy tytuł dla duchowych zarządców niektórych znaczących parafii. Łac. Admodum Reverendus Dominus, skrót: A.R.D. - [tłum. pol.: Wielce Wielebny Dziekan lub Przewielebny względnie Wielce
} 
10. Ale czemu to ma służyć takie przypominanie kolejnych przykładów skoncentrowanych wokół bezbożnych, niemoralnych i bezczelnych czynów? Och, jeżeliby się dało napisać na ich czoła to, czego Semiramida (Semiramis) dała sobie napisać na swoją trumnę: „Kiedy nie byłbyś bezbożnym człowiekiem, martwym byś nie przeszkadzał".

11. Jeszcze możemy przypomnieć, w jaki sposób dawali na jaw swoją wściekłość na samo imię Fridrich (z nienawiści do pobożnego króla, który zezwalał na przyjmowanie komunii pod dwoma postaciami). W 1622 roku mistrz Jan Libertin, mieszczanin Nowego Miasta Praskiego dał swojemu synowi na imię Fridrich. Przez to najpierw męczyli go przywołani w sporej ilości niesforni żołnierze, którzy go ukarali grzywną w wysokości 500 talarów. Normalne było również targanie obrazów z Fridrichem, deptanie ich i wydłubywanie oczu oraz zgładzanie osób, jeżeli były u kogoś znalezione. Czyli nawet tylko pomyślenie o Fridrichowi pachniało karą śmierci.

\section{Bibliografia}

Bartoš František Michálek, Předmluva k předchozímu prvorepublikovému vydání z r. 1922, W: Historie o těžkých protivenstvích církve české. Vjazyce 21. století. Do jazyka 21. století, Vyd. Poutníkova četba, Chlumec 2018.

Bečková Marta, Przyczynki do działalności Jana Amosa Komeskiego w Polsce w świetle nowych badań, W: ,Rozprawy z Dziejów Oświaty“ 1979, t. XXII, s. 3-20.

Brodniewicz Joanna, Czeski Kościół katolicki w zsekularyzowanym społeczeństwie, Wyd. Uniwersytet Adama Mickiewicza, Poznań 2016.

Hanuš Bohumil, Dějiny a působení jesuitského rádu kutnohorského, Nakl. Kuttna, Kutná Hora 2012.

Harasimowicz Zofia, Patryn Bogdan, Epitafium Adama Augustinusa, proboszcza w Strzyżowie w latach 1597-1636, „Strzyżowski Rocznik Muzealny”, t. III., Strzyżów 2017, s. 63-67.

Herain Jan, Teige Josef, Poprava na Staroměstském rynku v Praze 21. června r. 1621. Vyd. Společnost přátel starožitností českých, Praha 1904.

Herben Jan, Poprava českých pánů na Staroměstském náměstí v Praze 21. června 1621. Nakl. Mladé proudy, Praha 1921.

Hrohowie Mirosław i Věra, Z nowszych prac o Janie Amosie Komeńskim, W: „Śląski Kwartalnik Historyczny Sobótka“, Wrocławskie

szanowny, gdzie określenie Dominus może w odniesieniu do osoby duchownej oznaczać godność kanonika] (por. Harasimowicz, Patryn 2017: 65; Makarczyk 2005: 280). 
Towarzystwo Miłośników Historii, tom 14 (1959), s. 407-417, także http://sobotka.uni.wroc.pl/wpcontent/uploads/2017/06/Sobotka_14_ 1959_3_407-417.pdf

Kadlec Jaroslav, Přehled českých církevních dějin. 1. a 2. díl, Nakl. Zvon, Praha 1991.

Komenský Jan Amos, Historie o těžkých protivenstvích církve české. Vjazyce 21. století. Do jazyka 21. století převedli Lukáš Makovička a Jiří Kostelník, Vyd. Poutníkova četba, Chlumec 2018.

Kratochvíl Miloš, Život Jana Amose, Vyd. Československý spisovatel, Praha 1975.

Kraus Jiří a kol., Nový akademický slovník cizích slov A-Ž, Nakladatelství Akademia, Praha 2007.

Lehár Jan, Stich Alexander, Janáčková Jaroslava, Holý Jiří, Česká literatura od počátku k dnešku, Nakladatelství Lidové noviny, Praha 2004.

Makarczyk Irena, Wojciech Nowiejski (ok. 1620-1664) kanonik warmiński dobroczyńca miasta Olsztyna, „Komunikaty Mazursko-Warmińskie” 2005, nr 3(249), s. 279-313.

Molnár Daniel Bohumil, Hlavy mučenníků bělohorských, Praha: vl.n., 1882.

Nedvědová Milada, Graus František, Hus a Jeronym v Kostnici. Série: Živá díla minulosti, Státní nakladatelství krásné literatury, hudby a umění, Praha 1953.

Pavlas Petr, Trinus liber Dei: Komenského místo v dějinách metaforiky knihy. Vyd. Nakladatelství Pavel Mervart, Červený Kostelec 2015.

Petráň Josef, Staroměstská exekuce. Několik stránek z dějin povstání feudálních stavů proti Habsburkům v letech 1618-1620, Nakl. Mladá fronta, Praha 1972.

Petráň Josef, Staroměstská exekuce. Rodiče, 4. vyd. Praha 2004.

Purš Jaroslav, Kropilák Miroslav et al.: Přehled dějin Československa I/2 (1526-1848), Nakl. Academia, Praha 1982.

Sitarska Barbara, Jan Amos Komeński w trzecim tysiącleciu. Odczytania kontynuacje - krytyka „Siedleckie Zeszyty Komeniologiczne, seria pedagogika", t. V, Jan Amos Komeński wepoce współczesności. Odczytania - kontynuacje - krytyka, Siedlce 2018, s. 211-250.

Svátek Josef, Paměti katovské rodiny Mydlářo - rozličné príběhy katovské, 2. díl, Nakladatelství XYZ, Praha 2005.

Vrabec Jan Josef, Popravy na Staroměstském náměstí 21. června 1621, Nákladem B. Kočího v Praze 1908.

Wandycz Piotr, Cena wolności. Historia Europy Środkowo-Wschodniej od średniowiecza do współczesności, przeł. T. Wyrozumski, Wyd. Znak, Kraków 1995. 


\section{Wykaz skrótów przekładów biblijnych:}

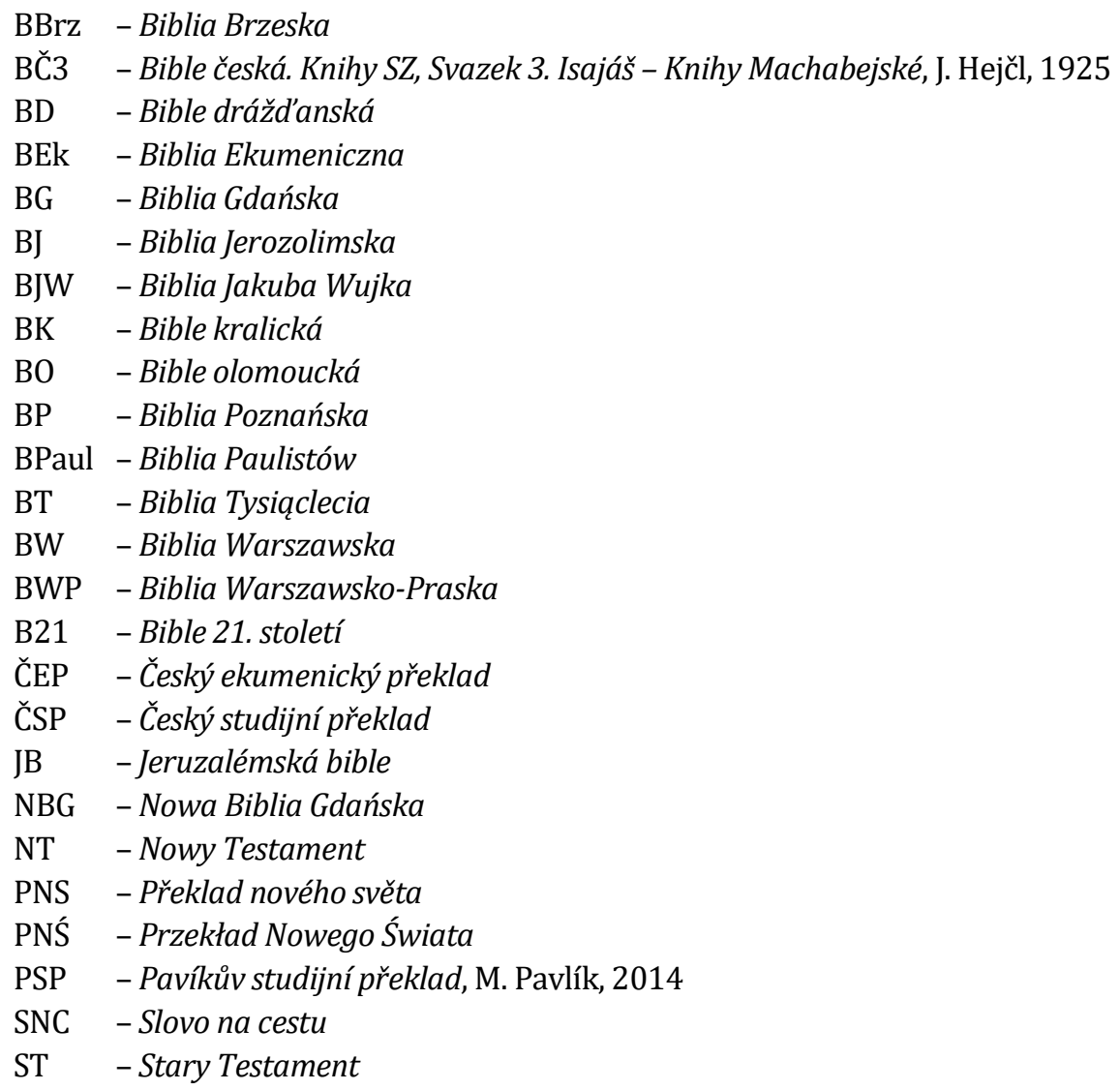

